\title{
Pembuatan Jadwal Shift Perawat Dengan Menggunakan Metode Constraint Satisfaction
}

\author{
Rizal Rakhman Mustafa ${ }^{* 1}$, Yufis Azhar ${ }^{2}$, Nur Hayatin ${ }^{3}$ \\ 1,2,3Teknik Informatika/Universitas Muhammadiyah Malang \\ rizal.rakhman07@gmail.com ${ }^{*}$, yufis@umm.ac.id ${ }^{2}$, noorhayatin@gmail.com ${ }^{3}$
}

\begin{abstract}
Abstrak
Rumah Sakit adalah institusi pelayanan kesehatan yang menyelenggarakan pelayanan kesehatan perorangan secara paripurna yang menyediakan pelayanan rawat inap, rawat jalan dan gawat darurat. Rumah Sakit mempunyai beberapa Sumber daya dari suatu fasilitas kesehatan seperti, perawat, dokter dan peralatan medis harus tersedia selama 24 jam sehari dalam satu minggu. Bagi perawat panjangnya jam kerja dapat berdampak buruk pada pelayanan kesehatan dan kualitas kerja, oleh sebab itu penjadwalan merupakan hal yang sangat penting dan membatu perawatan dalam meningkatkan pelayanan kesehatan dan kualitas kerja. Penjadwalan ini diharapkan dapat membatu kepala ruang untuk mendapatkan jadwal dengan beban jam kerja lebih efektif untuk setiap perawat serta memenuhi batasan - batasan penjadwalan yang ada. Constraint Programing (CP) merupakan pendekatan perhitungan atau komputasi matematis atas masalah - masalah yang berkaitan dengan batasan - batasan dari variabel - variabel, dengan tujuan mencari solusi yang memenuhi batasan - batasan tersebut. Setelah melakukan evaluasi terhadap penelitian ini, dapat disimpulkan bahwa penggunaan algoritma Constraint Satisfaction untuk pembuatan jadwal shift perawat ini dinilai cukup efektif. Keberhasilan dalam penjadwalan ini mencapai $99.2 \%$ dan $94 \%$.
\end{abstract}

Kata Kunci: Penjadwalan, Shift Perawat, Rumah Sakit, Constraint Satisfaction

\section{Abstract}

Hospitals are institution health services that runs health services in plenary individual that provides inpatient service, outpatient and emergency. Hospitals have some resources of a health facilities as, nurses, doctors and medical equipment should be made available for 24 hours a day of the week. Nurses long for working hours may hurt the health services and the quality of work, therefore scheduling is very important and petrified care in improve health services and quality of work. Scheduling is expected to petrified the space to get schedule with a working hours more effective for each nurses and meet the existing scheduling. Constraint Programing $(C P)$ is approach reckoning or computation mathematical to problems relating to the boundaries of variable, with the purpose of finding a solution that meet the the After doing evaluation to the research, can be concluded that the use of algorithm constraint satisfaction for the manufacture of schedule shift nurse was considered quite effective. Success in scheduling will reach $99.2 \%$ and $94 \%$.

Keywords: Scheduling, Shift Nurse, Hospital, Constraint Satisfaction

\section{Pendahuluan}

Rumah Sakit adalah institusi pelayanan kesehatan yang menyelenggarakan pelayanan kesehatan perorangan secara paripurna yang menyediakan pelayanan rawat inap, rawat jalan dan gawat darurat [1]. Dimana salah satu fasilitas pelayanan kesehatan yang ada adalah Rumah Sakit, Rumah Sakit Bhayangkara Hasta Brata merupakan Salah satu Rumah Sakit yang berada di Kota Batu. Pada Rumah Sakit Bhayangkara Hasta Brata ada beberapa Ruang Rawat Inap Pasien, dan semua ruang dikepalai oleh satu kepala ruang yang bertugas membuat jadwal shift kerja perawat ruang.

Rumah Sakit mempunyai beberapa Sumber daya dari suatu fasilitas kesehatan seperti, perawat, dokter dan peralatan medis harus tersedia selama 24 jam sehari dalam satu minggu. Bagi perawat panjangnya jam kerja dapat berdampak buruk pada pelayanan kesehatan dan kualitas kerja, untuk menghindarinya salah satu cara yang diusahakan oleh menejemen Rumah Sakit yang diwakili Kepala Ruang adalah dengan memberikan penjadwalan kerja pada perawat 
yang tersedia [2]. Penjadwalan ini merupakan hal yang sangat penting dan membatu perawatan dalam meningkatkan pelayanan kesehatan dan kualitas kerja. Penjadwalan ini diharapkan dapat membatu kepala ruang untuk mendapatkan jadwal dengan beban jam kerja lebih efektif untuk setiap perawat serta memenuhi batasan-batasan penjadwalan yang ada.

Constraint Programing (CP) merupakan pendekatan perhitungan atau komputasi matematis atas masalah - masalah yang berkaitan dengan batasan - batasan dari variabel variabel, dengan tujuan mencari solusi yang memenuhi batasan - batasan tersebut [3]. Masalah yang harus diselesaikan dalam CP disebut dengan Constraint Satisfaction Problem (CSP). Pemodelan CSP yang lengkap terdiri dari himpunan variable (data yang nilainya dapat berubah - ubah), himpunan domain (nilai yang mungkin untuk setiap variabel), dan himpunan constraint (batasan yang harus dipenuhi oleh setiap variabel).

Pentingnya penggunaan metode Constraint Satisfaction didukung dengan adanya penelitian - penelitian sebelumnya terkait dengan pembuatan jadwal yang bisa dijadikan referensi dalam pembuatan tugas akhir ini. Diantaranya pada penelitian yang dilakukan oleh Reta Wulansari [4]. Dalam penelitian tersebut data yang digunakan terdiri nama penyiar, program siaran dan waktu siaran radio UMM FM. Data tersebut digunakan sebagai acuan dalam penjadwalan siaran di radio UMM FM. Kemudian penelitaian sebelumnya yang terkait adalah "Penggunaan Metode Algoritma Genetik Dengan Pemodelan Dua Tingkat Dalam Permasalahan Data Perawat Pda Unit Gawat Darurat Rumah Sakit Umum XYZ Surabaya" penelitian oleh Anisa Ulya ini dilakukan dengan menggunakan Algoritma Genetik dua tingkat, dimana tingkat pertama dilakukan untuk penjadwalan hari libur perawat, pada tingkat kedua untuk menentukan hari kerja perawat. Yang diharapakan dari peneitian tersebut adalah pemodelan yang dirancang diharapkan dapat memenuhi batasan yang berlaku disetiap permodelan dan mendekati jadwal kerja yang diinginkan oleh perawat. Selanjutnya penelitian yang tekait adalah penelitian yang dilakukan oleh Yufis Azhar dengan judul "Pengembangan Aplikasi Penjadwalan Matakuliah Dengan Menggunakan Algoritma Constraint Satisfaction", pada penelitian ini dilakukan penjadwalan dengan menggunakan metode Constraint Satisfaction, dimana metode ini menggunakan batasan - batasan yang diperlukan untuk menyusun jadwal mata kuliah [5].

Pada penelitian ini, data yang dibutuhkan untuk penelitian dan perancangan sistem adalah data perawat ruang, aturan - aturan yang berlaku untuk pembuatan jadwal shift perawat, dan jadwal shift kerja perawat selama 2 - 4 bulan terakhir. Sedangkan untuk sistem pada tugas akhir ini, ada 3 shift dalam satu hari yaitu, pagi, siang, dan malam, dan setiap perawat mendapatkan libur $4-5$ hari untuk perawat, dan 8 hari untuk kepala ruang dalam satu bulan. Satu bulan dalam kalender pada sistem ini yaitu 30 hari. Kemudian untuk perawat, setelah 2 hari shift malam mendapatkan libur 1 hari dihari berikutnya. Diharapkan dengan sistem ini dapat membantu Kepala Ruang untuk menentukan jadwal shift kerja perawat.

\section{Metode Penelitian}

Penjadwalan merupakan alokasi dari sumber daya terhadap waktu untuk menghasilkan sebuah kumpulan pekerjaan. Penjadwalan dibutuhkan untuk memproduksi permintaan dengan mengalokasikan sumber daya yang tepat seperti mesin yang digunakan, jumlah operator yang bekerja, urutan pengerjaan, dan kebutuhan material. Dengan pengaturan penjadwalan yang efektif dan efisiean, perusahaan dapat memenuhi permintaan waktu serta kualitas yang telah ditentukan [6].

Penjadwalan diperlukan ketika beberapa pekerjaan harus diproses pada waktu tertentu yang tidak akan memproses lebih dari satu pekerjaan pada saat yang sama. Penjadwalan yang baik akan memaksimalkan efektivitas pemanfaatan setiap sumber daya yang ada, sehingga penjadwalan merupakan kegiatan yang penting dalam perencanaan pengendalian produksi.

Constraint Satisfaction Problem (CSP) merupakan sebuah pendekatan dari problem yang bersifat matematis dengan tujuan menemukan keadaan atau obyek yang memenuhi sejumlah batasan (constraint) yang sudah ditetapkan. Batasan tersebut memperlihatkan nilai-nlai yang diperbolehkan untuk variable, dan selanjutnya solusi merupakasn suatu evaluasi dari variablevariable yang memenuhi batasan yang ditetapkan [5].

Untuk dapat mememcahkan permasalahan tersebut dibutuhakan suatu formula. Menemukan formula pemecahan yang tepat dari kombinasi permasalahan yang merupakah tujuan utama dari algortima Constraint Satisfaction. Untuk dapat menemukan formula ini, terlebih dahulu kita harus memodelkan masalah-masalah yang ada dalam suatu Constraint Satisfaction Problem (CSP) [7]. Umumnya Constraint Satisfaction Problem ini akan didefinisikan ke dalam

REPOSITOR, Vol. 2, No. 2, Februari 2020: 239-248 
suatu trilet $(X, C, D)$ seperti di bawah ini :

1. Variable : $X=\{X 1, X 2, \ldots . . X n\}$ adalah kumpulan himpunan variable dari suatu masalah.

2. Domain : $\mathrm{D}$ adalah suatu fungsi (himpunan) dari nilai yang mngkin untuk setiap variable $X$

3. Constraint : $\mathrm{C}=\{\mathrm{C} 1, \mathrm{C} 2, \ldots . . \mathrm{Ck}\}$ adalah kumpulan dari Constraint. Setiap Constraint adalah suatu penghubung antara himpunan variable yang membatasi domain atau nilai yang mungkin dari setiap variable.

Karena programnya dapat dibuat dan dimodifikasi dengan cepat, maka sangat mungkin untuk bereksperimen mendapatkan penyelesaian dengan program terbaik dan waktu komputasi cepat. Constraint secara pemenuhan prioritasnya dapat dibedakan menjadi 2 (dua) bagian [8], yaitu:

- Hard Constraint

adalah persyaratan yang harus dipenuhi dan tidak boleh dilanggar dalam pembuatan penyelesaian masalah. Pada penelitian ini hard constraint-nya berupa :

a) Pada Ruang Inap Rumah Sakit Bhayangkara Hasta Brata Batu ada beberapa kategori karyawan yaitu, Kepala Ruang, perawat.

b) Pada jadwal ada tiga shift dalam satu hari yaitu, pagi, siang dan malam.

c) Pada jadwal Kepala Ruang hanya hanya ada shift pagi.

d) Pada jadwal perawat, setelah 2 hari shift malam berurutan mendapat libur 1 hari dikeesokan harinya.

e) Setelah sihift malam keesokan harinya tidak boleh shift pagi.

- Soft Constraint

adalah persyaratan tambahan yang biasanya merupakan sebuah permintaan khusus, tanpa adanya konsekuensi fatal jika tidak terpenuhi. Pada penelitian ini soft constraint-nya berupa

a) Pada jadwal Kepala Ruang hanya ada 5 hari kerja berurutan dalam satu minggu.

b) Hari libur dalam satu bulan ada $4-5$ hari / ada 1x libur diantara 7 hari kerja.

c) Kepala ruang mendapatkan libur 8 hari dalam 1 bulan.

d) Pada setiap shift minimal ada 3 orang perawat yang bertugas..

Pada permasalahan penjadawlan shift perawat dapat dilihat pada Persamaan 1 [9].

$$
\odot=\{\mathrm{V}, \mathrm{D}, \mathrm{C}\}
$$

Dimana :

$\mathrm{V}$ : jumlah total perawat

$D$ : jumlah shift dalam satu bulan

C : batasan - batasan yang ditetapkan

- Variable ( V )

Variable dari Constraint Satisfaction Problem pada penjadwalan shift perawat ini adalah jumlah total perawat yang ada pada rumah sakit.

- Domain ( D )

Domain dari Constraint Satisfaction Problem pada penjadwalan shift perawat ini adalah himpunan jumlah perawat yang melakukan shift pada tiap shift, satu hari ada tiga shift, dan jumlah slot waktu yang dapat digunakan untuk tiap pertemuan.

- Constraint ( C )

Constraint dari Constraint Satisfaction Problem pada penjadwalan shift perawat ini adalah batasan - batasan dalam penyusunan suatu jadwal yang telah dibagi dalam 2 kategori yaitu, shoft Constrint dan hard Constraint, dimana batasan - batasan yang ditentukan untuk shoft Constrint dan hard Constraint sudah ditetapkan sebelumnya.

\section{Hasil Penelitian dan Pembahasan}

Hasil dari penelitian ini adalah suatu bentuk system yang dapat membantu kepala ruang dapal proses penjawalan shift perawat, dimana system ini merupakan system yang berbasis web dengan menerapkan metode constraint satisfaction. Berikut hasil yang diperoleh pada penelitian ini: 


\subsection{Usecase}

Usecase diagram merupakan pemodelan strukturan yang menggambarkan secara garis besar dari sistem beserta fitur-fitur yang dimiliki.

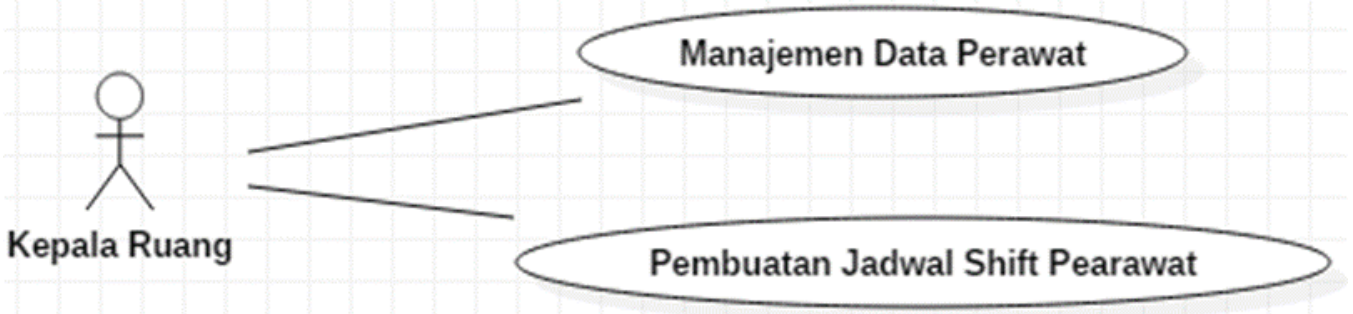

Gambar 1. Use case diagram Admin

Gambar 1 menunjukkan Use Case diagram dalam sistem ini. Use case untuk kepala ruang yang bertindak sebagai admin. Pada gambar tersebut admin memiliki 2 hak akses, yaitu yang pertama admin memiliki hak akses untuk me-manajemen data perawat yang meliputi create, read, update dan delete pada data perawat dan hak akses yang kedua adalah membuat jadwal shift perawat.

\subsection{Class}

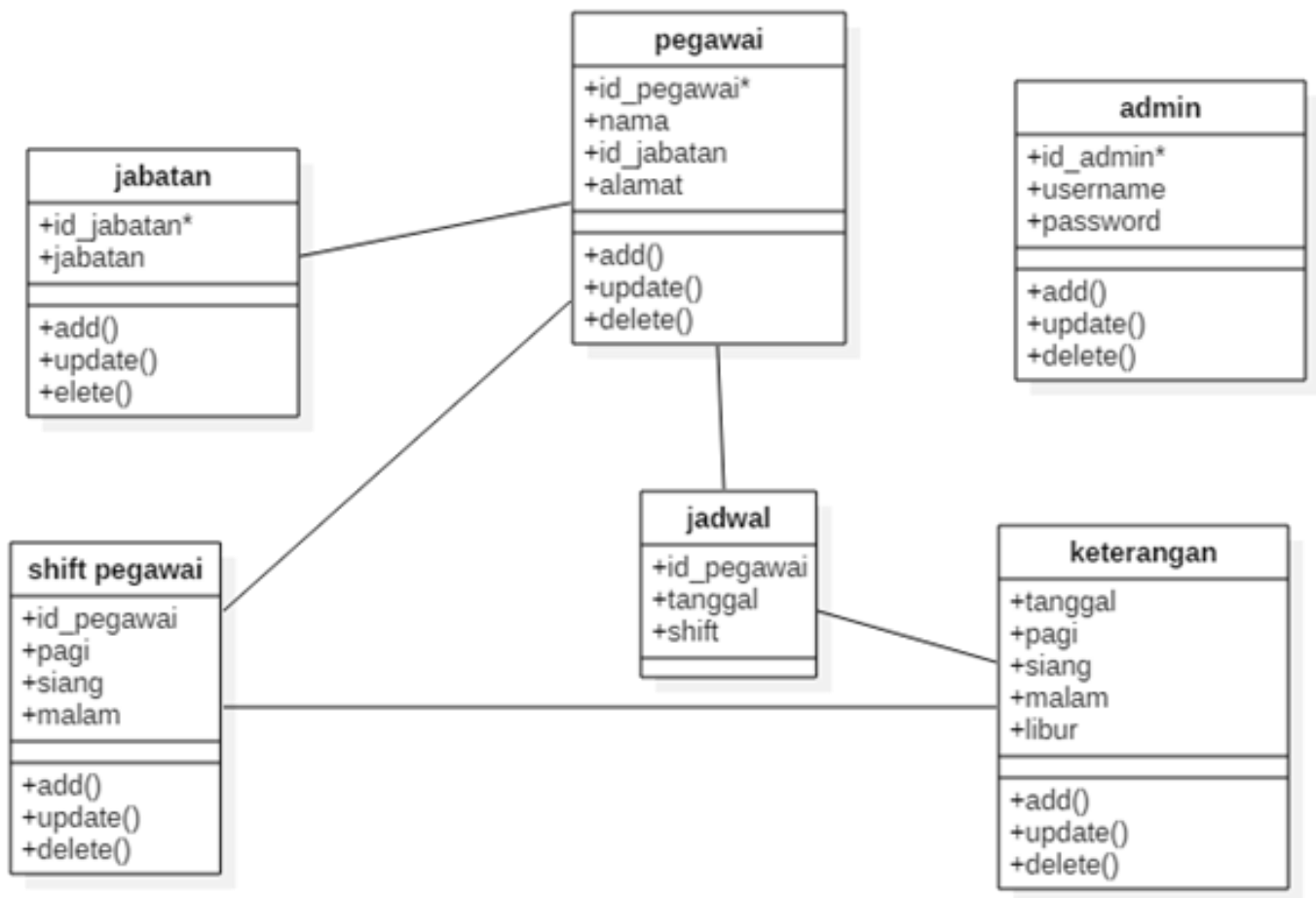

Gambar 2. Class Diagram Penjadwalan Shift Perawat

Class diagram adalah diagram yang digunakan untuk menampilkan beberapa kelas serta paket-paket yang ada dalam sistem/perangkat lunak yang sedang dikembangkan dimana diagram ini memberikan gambaran (diagram statis) tentang sistem/perangkat lunak dan relasirelasi yang ada di dalamnya. Class diagram perawat yang dihasilkan terdapat dalam Gambar 2.

\subsection{Implementasi}

\subsubsection{Halaman Data Pegawai}

Pada Gambar 3 menjelaskan tentang halaman pegawai, dimana halam ini digunakan oleh admin ( kepala ruang ) untuk mengelola data pegawai, mulai dari menambah data pegawai baru, meng-upadate data perawat yang sudah ada, sampai menghapus data pegawai. 


\begin{tabular}{|c|c|c|c|c|c|c|c|}
\hline \multicolumn{3}{|c|}{ Data Pegawai } & \multicolumn{2}{|l|}{ Search for. } & a & \multicolumn{2}{|c|}{ + Tambah Data } \\
\hline No & ID Pegawai & Nama Pegawai & Jabatan & Alamat & & & \\
\hline 1 & $P_{12}$ & Set Aftah & Perawat & Lamongan & & a ubah & 8 Houn \\
\hline 2 & P11 & Wulan Vtasari & Perawat & Junrejo Batu & & Q Uboh & 8 Hepus \\
\hline 3 & P10 & Toufk Hsdayat & Perswat & Pamekason & & Q ubet & A Haps \\
\hline 4 & P0O & Fenkiks Irms & Perawat & Junrejo Batu & & a ubah & B Hopus \\
\hline 5 & P06 & M. Foizin & Perswat & Pasuruan & & a Uban: & 8 Hipus \\
\hline 6 & P07 & M. Fatchurrahman & Perawat & Nganjuk & & a uow & B Hepos \\
\hline 7 & P06 & Angga Gigih & Perawat & Nganjuk & & Q U uboh & 8 Hepus \\
\hline 8 & P05 & Hasan Khumaidi & Perawat & Trenggalek & & Q ubeh & B rapes \\
\hline 9 & PO4 & Fendi Setyo Utomo & Perawat & Madiun & & a uboh & 8 Hons \\
\hline 10 & P03 & Rinowati & Perawat & Ponorogo & & $a$ Ubah & 8 Hopus. \\
\hline Se & & & & & & & Selan \\
\hline
\end{tabular}

Gambar 3. Tampilan Halaman Data Pegawai

\subsubsection{Halaman Penjadwalan}

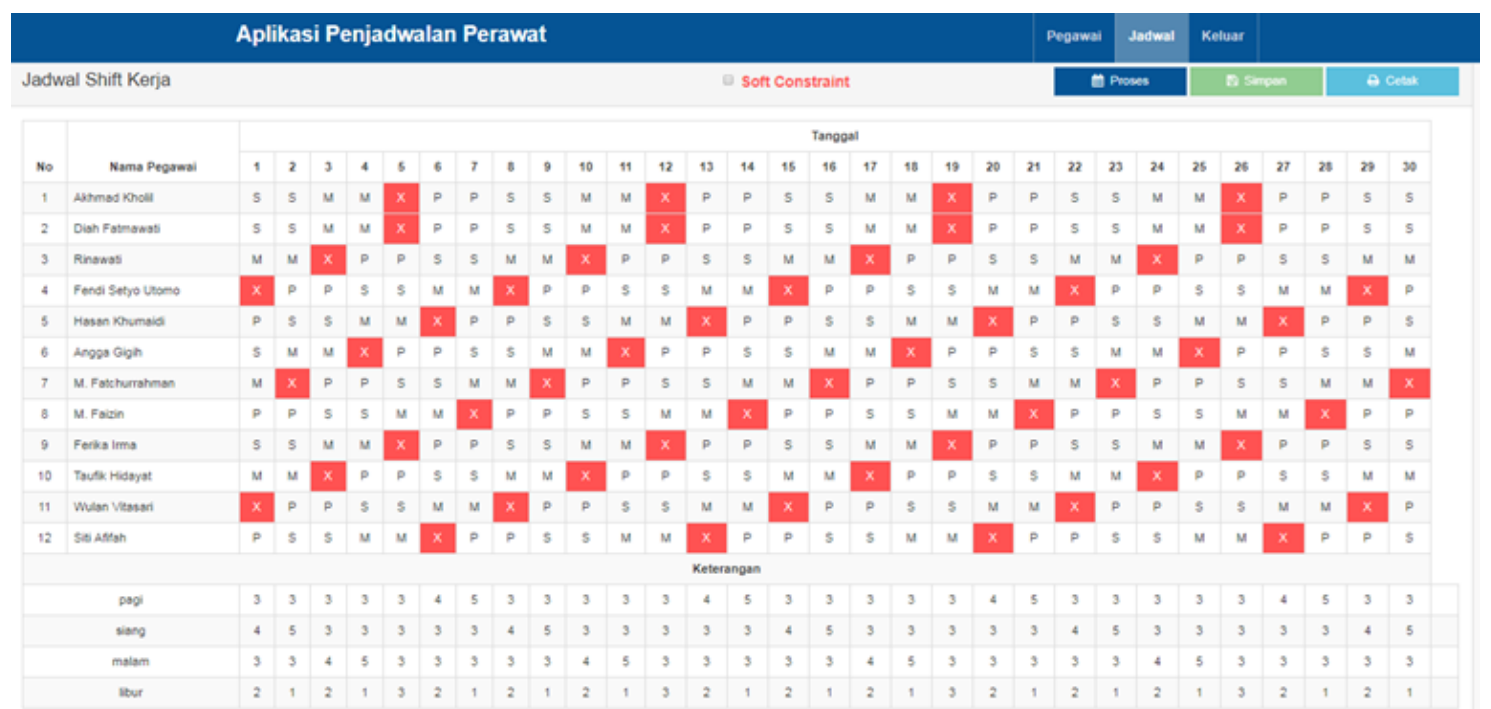

Gambar 4. Tampilan Halaman Penjadawalan

Paga Gambar 4 menunjukan halaman penjadwalan shift perawat, dimana penjadwalan ini digunakan oleh kepala ruang untuk menentukan shift yang akan dijadwalkan untuk perawat selama 30 hari kedepan. Pada halaman ini ada 3 tombol yang berfungsi untuk membantu kepala ruang dalam proses penjadwalan, dimana tombol pertama yaitu tombol Proses digunakan untuk me-load $\neg$ pola, sebelumnya sudah ada beberapa pola yang disimpan untuk proses penjadwalan shift perawat. Tombol yang kedua, yaitu tombol Simpan dimana tombol ini berfungsi untuk menyimpan pola yang akan dijadwalkan pada 30 hari kedepan. Kemudian tombol yang terakhir yaitu tombol Cetak, tombol ini berfungsi untuk mencetak penjadwalan yang sudah disimpan melalui tombol Simpan sebelumnya. 


\subsection{Analisa dan hasil Pengujian}

Analisa hasil pada pengujian kali ini dilakukan untuk melihat hasil dari proses penjadwalan dengan menggunakan pengujian akurasi. Skenario pengujian akurasi ini dilakukan sebanyak tujuh kali sesuai dengan pola yang digunakan untuk membuat penjadwalan sebelumnya, dimana pengujian akan menguji apakah hard constraint dan soft constraint ada yang terlanggar atau tidak, jika ada yang terlanggar maka akan diberikan nilai sebesar 0.5 untuk soft constraint yang terlanggar, dan 1 poin untuk hard constraint yang terlanggar, dan jika tidak ada hard constraint dan soft constraint yang terlanggar maka akan diberi nilai 0 . Setelah nilai hard constraint dan soft constraint dijumlah maka hasil tersebut akan dikurangi sejumlah total variable yang diuji, yaitu sebanyak 360 variable.

Jadi pada pengujian kali ini akan menggunakan pengujian akurasi untuk menentukan tingkat akurasi pengujian yang didapatkan.[10] Pengujian ini menggunakan Persamaan 2.

$$
\begin{aligned}
& \text { Akurasi } \\
& =\frac{\text { jumlah seluruh variable }-(\text { hasil dari pelanggaran hard }+ \text { soft constraint })}{\text { jumlah seluruh variable }} \times 100 \%
\end{aligned}
$$

\subsubsection{Pola Penjadwalan Acak}

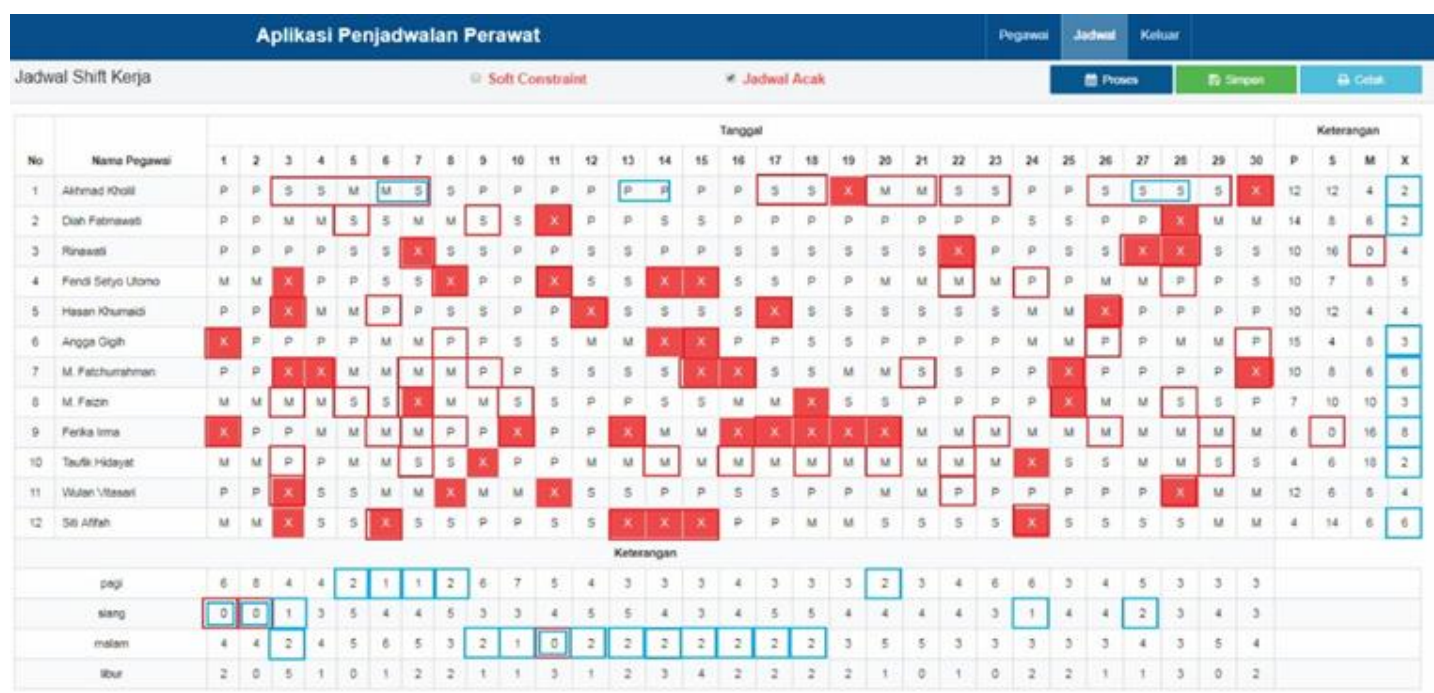

Gambar 5. Tampilan Halaman Jadwal Acak

Pada Gambar 5 menunjukan bahwa penjadwalan yang dilakukan secara acak akan banyak melanggar dari aturan yang sudah ditetapkan dengan baik, hard constraint maupun soft constraint, dan pada pola ini memiliki nilai akurasi sebesar hasil pada Tabel 1.

Tabel 1. Hasil Pengujian Acak

\begin{tabular}{clcc}
\hline \multicolumn{1}{c}{ PENGUJIAN } & & \\
\hline NO & \multicolumn{1}{c}{ HARD CONSTRAINT } & $\begin{array}{c}\text { JUMLAH YANG } \\
\text { DILANGGAR }\end{array}$ & $\begin{array}{c}\text { TOTAL * }^{*} \\
1\end{array}$ \\
\hline 1 & $\begin{array}{l}\text { Pada jadwal ada tiga shift dalam satu hari yaitu, } \\
\text { pagi, siang dan malam. }\end{array}$ & 5 & 5 \\
\hline 2 & $\begin{array}{l}\text { Pada jadwal Kepala Ruang hanya hanya ada shift } \\
\text { pagi. }\end{array}$ & 16 & 16 \\
\hline 3 & $\begin{array}{l}\text { Pada jadwal perawat, setelah 2 hari shift malam } \\
\text { berurutan mendapat libur 1 hari dikeesokan } \\
\text { harinya }\end{array}$ & 84 & 84 \\
\hline 4 & $\begin{array}{l}\text { Setelah sihift malam keesokan harinya tidak boleh } \\
\text { shift pagi }\end{array}$ & 10 & 10 \\
\hline & & & 115
\end{tabular}

REPOSITOR, Vol. 2, No. 2, Februari 2020: 239-248 


\begin{tabular}{clcc}
\hline NO & \multicolumn{1}{c}{ SOFT CONSTRAINT } & $\begin{array}{c}\text { JUMLAH YANG } \\
\text { DILANGGAR }\end{array}$ & $\begin{array}{c}\text { TOTAL * } \\
0.5\end{array}$ \\
\hline 1 & $\begin{array}{l}\text { Pada jadwal Kepala Ruang hanya ada 5 hari kerja } \\
\text { berurutan dalam satu minggu. }\end{array}$ & 6 & 3 \\
\hline 2 & $\begin{array}{l}\text { Hari libur perawat dalam satu bulan ada 4 -5 } \\
\text { ada 1 x libur diantara 7 hari kerja ) }\end{array}$ & 7 & 3.5 \\
\hline 3 & Hari libur kepala ruang ada 8 x dalam satu bulan & 1 & 0.5 \\
\hline 4 & $\begin{array}{l}\text { Pada setiap shift minimal ada 3 orang perawat } \\
\text { yang bertugas. }\end{array}$ & 22 & 11 \\
\hline & & & 18 \\
\hline
\end{tabular}

$$
\begin{gathered}
\begin{array}{l}
\text { Akurasi } \\
\text { jumlah seluruh variable }-(\text { hasil dari pelanggaran hard }+ \text { soft constraint })
\end{array} \\
\text { jumlah seluruh variable } \\
\text { Akurasi }=\frac{360-(115+18)}{360} \times 100 \% \\
\text { Akurasi }=\frac{227}{360} \times 100 \%=63.05 \%=63.1 \%
\end{gathered}
$$

Jadi hasil pada pengujian dengan penjadwalan acak hasil yang didapat sebesar $63.1 \%$

Hasil dari pembuatan jadwal secara acak ini dirasa kurang cocok karena banyak pegawai yang jam kerjanya tidak ideal, yang dikhawatirkan dari tidak idealnya penjadwalan ini adalah kinerja pegawai yang kurang maksimal dalam kualitas kerja dan kualitas pelayanan saat menangani pasien.

Oleh karena itu agar pegawai mendapatkan efektifitas jam kerja perawat yang lebih baik pada hasil penjadwalan,maka disini digunakan beberapa pola untuk melakukan peroses penjadwalan, beberapa pola tersebut adalah sebagai berikut :
- PPSSMMX
- SSPPMMX
- MMXPPSS
- PPMMXSS
- PSMMXSP
- MMXSSPP
- SSMMXPP

\subsubsection{Pola Jadwal Pertama}

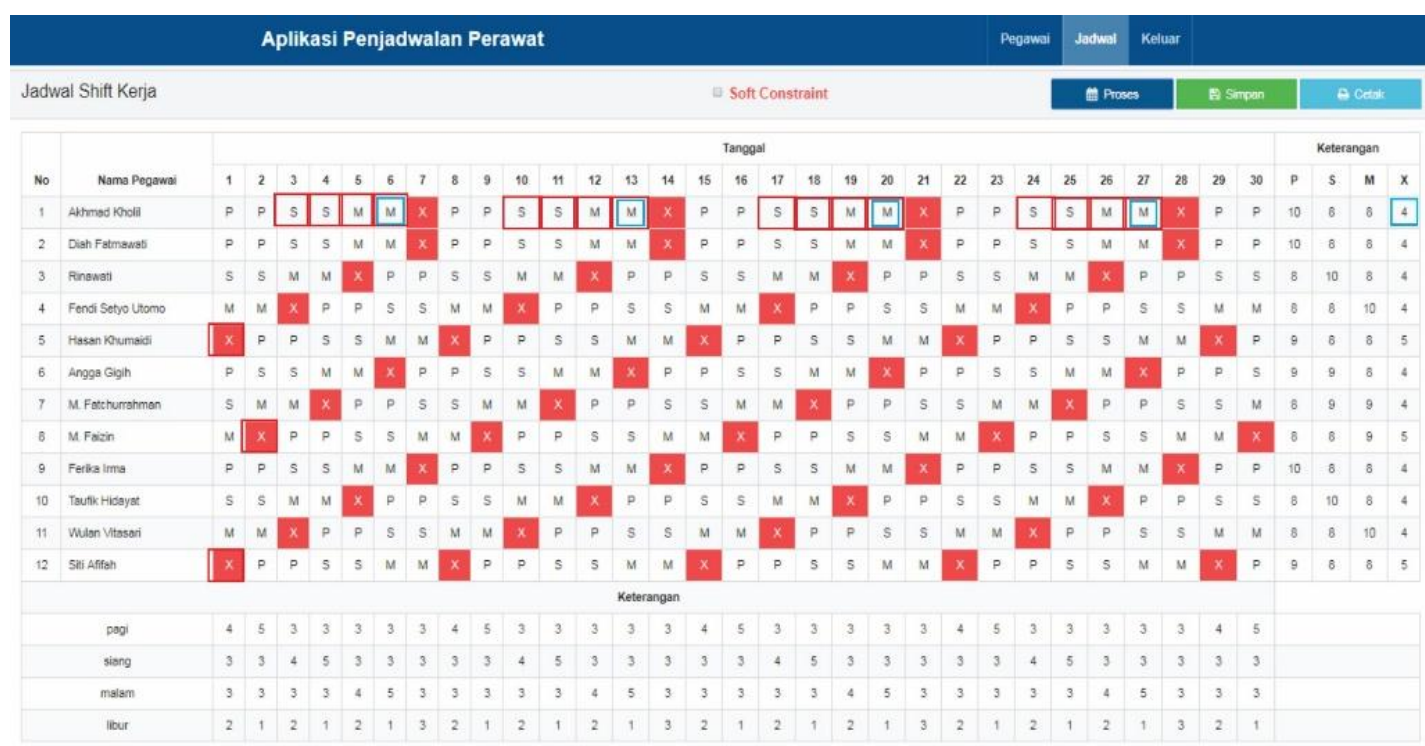

Gambar 6. Tampilan Halaman Jadwal Pertama

Pada Gambar 6 menunjukan bahwa penjadwalan yang dilakukan secara acak akan banyak melanggar dari aturanyang sudah ditetapkan baik, hard constraint maupun soft constraint, dan pada pola ini memiliki nilai akurasi sebesar nilai pada Tabel 2. 


\begin{tabular}{|c|c|c|c|}
\hline \multicolumn{4}{|c|}{ Tabel 2. Hasil Pengujian } \\
\hline NO & HARD CONSTRAINT & $\begin{array}{l}\text { JUMLAH YANG } \\
\text { DILANGGAR }\end{array}$ & TOTAL * 1 \\
\hline 1 & $\begin{array}{l}\text { Pada jadwal ada tiga shift dalam satu hari yaitu, } \\
\text { pagi, siang dan malam. }\end{array}$ & - & 0 \\
\hline 2 & $\begin{array}{l}\text { Pada jadwal Kepala Ruang hanya hanya ada shift } \\
\text { pagi. }\end{array}$ & 16 & 16 \\
\hline 3 & $\begin{array}{l}\text { Pada jadwal perawat, setelah } 2 \text { hari shift malam } \\
\text { berurutan mendapat libur } 1 \text { hari dikeesokan } \\
\text { harinya }\end{array}$ & 3 & 3 \\
\hline 4 & $\begin{array}{l}\text { Setelah sihift malam keesokan harinya tidak boleh } \\
\text { shift pagi }\end{array}$ & - & 0 \\
\hline & & & 19 \\
\hline NO & SOFT CONSTRAINT & $\begin{array}{l}\text { JUMLAH YANG } \\
\text { DILANGGAR }\end{array}$ & $\begin{array}{l}\text { TOTAL * } \\
0.5 \\
\end{array}$ \\
\hline 1 & $\begin{array}{l}\text { Pada jadwal Kepala Ruang hanya ada } 5 \text { hari kerja } \\
\text { berurutan dalam satu minggu. }\end{array}$ & 4 & 2 \\
\hline 2 & $\begin{array}{l}\text { Hari libur perawat dalam satu bulan ada } 4-5 \text { ( } \\
\text { ada } 1 \times \text { libur diantara } 7 \text { hari kerja ) }\end{array}$ & - & 0 \\
\hline 3 & Hari libur kepala ruang ada $8 x$ dalam satu bulan & 1 & 0.5 \\
\hline 4 & $\begin{array}{l}\text { Pada setiap shift minimal ada } 3 \text { orang perawat } \\
\text { yang bertugas. }\end{array}$ & - & - \\
\hline & & & 2.5 \\
\hline
\end{tabular}

$$
\begin{gathered}
\begin{array}{c}
\text { Akurasi } \\
\text { jumlah seluruh variable }-(\text { hasil dari pelanggaran hard }+ \text { soft constraint })
\end{array} \\
\text { jumlah seluruh variable } \\
\text { Akurasi }=\frac{360-(19+2.5)}{360} \times 100 \% \\
\text { Akurasi }=\frac{338.5}{360} \times 100 \%=94.02 \%=94 \%
\end{gathered}
$$

Jadi hasil pada pengujian pertama hasil yang didapat sebesar $94 \%$

Pada Gambar 6 dan Tabel 2 diatas menunjukan salah satu contoh pola penjadwalan dimana kepala ruang masih mengikuti pola dari penjadwalan, jadi jika dirangking pola mana saja yang paling baik hasilnya maka akan mendapatkan hasil seperti pada Tabel 3.

Tabel 3. Ranking Pola

\begin{tabular}{ccc}
\hline No & Pola & Nilai \\
\hline 1 & PPSSMMX & $94 \%$ \\
2 & PPMMXSS & $94 \%$ \\
3 & MMXSSPP & $93.5 \%$ \\
4 & SSPPMMX & $93.5 \%$ \\
5 & SSMMXPP & $93.5 \%$ \\
6 & MMXPPSS & $93.5 \%$ \\
7 & PSMMXSP & $93.1 \%$ \\
\hline
\end{tabular}

\subsubsection{Pola Jadwal Kedua}

Pada Gambar 7 menunjukan bahwa penjadwalan yang dilakukan secara acak akan banyak melanggar dari aturanyang sudah ditetapkan baik, hard constraint maupun soft constraint, dan pada pola ini memiliki nilai akurasi sebesar nilai Tabel 4. 


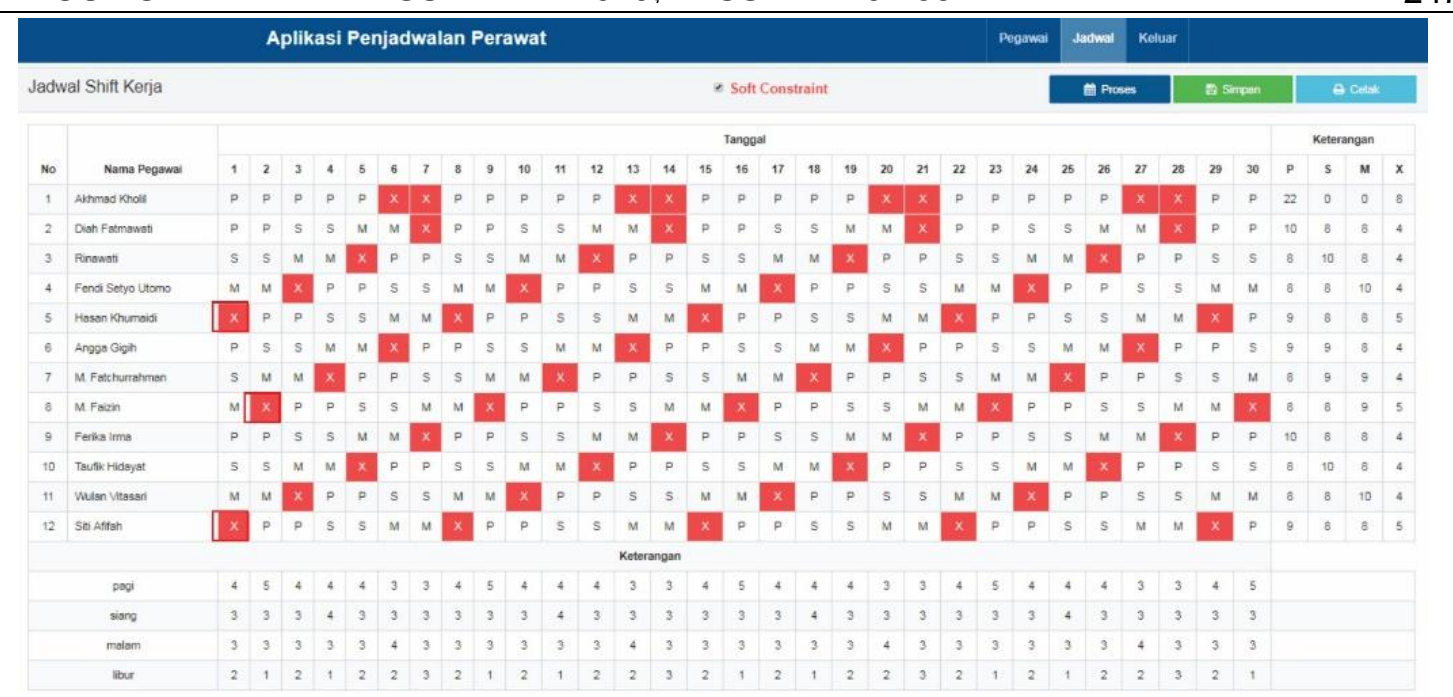

Gambar 7. Tampilan Halaman Jadwal Kedua

Tabel 4. Hasil Pengujian

\begin{tabular}{|c|c|c|c|}
\hline \multicolumn{4}{|c|}{ PENGUJIAN POLA PPSSMMX } \\
\hline NO & HARD CONSTRAINT & $\begin{array}{l}\text { JUMLAH YANG } \\
\text { DILANGGAR }\end{array}$ & $\begin{array}{c}\text { TOTAL * } \\
1\end{array}$ \\
\hline 1 & $\begin{array}{l}\text { Pada jadwal ada tiga shift dalam satu hari yaitu, } \\
\text { pagi, siang dan malam. }\end{array}$ & - & 0 \\
\hline 2 & $\begin{array}{l}\text { Pada jadwal Kepala Ruang hanya hanya ada } \\
\text { shift pagi. }\end{array}$ & - & 0 \\
\hline 3 & $\begin{array}{l}\text { Pada jadwal perawat, setelah } 2 \text { hari shift malam } \\
\text { berurutan mendapat libur } 1 \text { hari dikeesokan } \\
\text { harinya }\end{array}$ & 3 & 3 \\
\hline 4 & $\begin{array}{l}\text { Setelah sihift malam keesokan harinya tidak } \\
\text { boleh shift pagi }\end{array}$ & - & 0 \\
\hline & & & 3 \\
\hline NO & SOFT CONSTRAINT & $\begin{array}{l}\text { JUMLAH YANG } \\
\text { DILANGGAR }\end{array}$ & $\begin{array}{c}\text { TOTAL * } \\
0.5 \\
\end{array}$ \\
\hline 1 & $\begin{array}{l}\text { Pada jadwal Kepala Ruang hanya ada } 5 \text { hari } \\
\text { kerja berurutan dalam satu minggu. }\end{array}$ & - & 0 \\
\hline 2 & $\begin{array}{l}\text { Hari libur perawat dalam satu bulan ada } 4-5 \text { ( } \\
\text { ada } 1 x \text { libur diantara } 7 \text { hari kerja ) }\end{array}$ & - & 0 \\
\hline 3 & $\begin{array}{l}\text { Hari libur kepala ruang ada } 8 \times \text { dalam satu } \\
\text { bulan }\end{array}$ & - & 0 \\
\hline 4 & $\begin{array}{l}\text { Pada setiap shift minimal ada } 3 \text { orang perawat } \\
\text { yang bertugas. }\end{array}$ & - & - \\
\hline
\end{tabular}

\section{Akurasi}

$$
\begin{gathered}
=\frac{\text { jumlah seluruh variable }-(\text { hasil dari pelang garan hard }+ \text { soft constraint })}{\text { jumlah seluruh variable }} \times 100 \% \\
\text { Akurasi }=\frac{360-(3+0)}{360} \times 100 \% \\
\text { Akurasi }=\frac{357}{360} \times 100 \%=99.16 \%=99.2 \%
\end{gathered}
$$

Jadi hasil pada pengujian pertama hasil yang didapat sebesar $99.2 \%$

Pada Gambar 7 dan Tabel 4 diatas menunjukan salah satu contoh pola penjadwalan dimana kepala ruang sudah tidak mengikuti pola dari penjadwalan, jadi jika kepala ruang sudah memenuhi salah beberapa constraint yang diteteapkan yaitu : mendapat jadwal shift pagi dan 
masuk 5 hari kerja dalam 1 minggu. Maka apabila dirangking pola mana saja yang paling baik hasilnya maka akan mendapatkan hasil seperti pada Tabel 5.

Tabel 5. Ranking Pola

\begin{tabular}{ccc}
\hline No & Pola & Nilai \\
\hline 1 & PPSSMMX & $99.2 \%$ \\
2 & PPMMXSS & $99.2 \%$ \\
3 & MMXSSPP & $99.2 \%$ \\
4 & SSPPMMX & $99.2 \%$ \\
5 & SSMMXPP & $99.2 \%$ \\
6 & MMXPPSS & $99.2 \%$ \\
7 & PSMMXSP & $98.5 \%$ \\
\hline
\end{tabular}

\section{Kesimpulan}

Setelah melakukan evaluasi terhadap penelitian ini, dapat disimpulkan bahwa penggunaan algoritma constraint satisfaction untuk pembuatan jadwal shift perawat ini dinilai cukup efektif. Hal ini dikarenakan dalam menyusun suatu jadwal shift perawat, terdapat banyak sekali variable dan constraint yang terlibat, seperti :

1. Sistem penjadwalan shift perawat yang dibuat telah sesuai dan berhasil memenuhi semua constraint yang ditetapkan.

2. Hasil pengujian akurasi dari sistem penjadwalan shift perawat ini cukup memuaskan yaitu $94 \%$ dan $99.2 \%$ dan sudah sesuai dengan constraint.

\section{Saran}

Secara umum untuk ke depannya, ada saran pengembangan yang dapat dilakukan untuk pengembangan pada penelitian ini diantara lain :

1. Adanya penambahan fitur history, dimana diharapkan jika adanya fitur ini dapat melihat dan menyimpan penjadwalan yang sudah dibuat pada bulan sebelumnya dan akan berhubungan dengan penjadwalan yang akan dibuat untuk bulan selanjutnya.

2. Penambaha fitur real time, dimana banyaknya tanggal untuk penjadwalan sama dengan tanggal pada bulan di kalender sebenarnya.

3. Menggunakan skenario pengujian lainya, agar didapatkan hasil yang berbeda untuk mengukur tingkat keberhasilan pada system ini.

\section{Referensi}

[1] Presiden, Undang-Undang Republik Indonesia Nomor 44 Tahun 2009 Tentang Rumah Sakit. Republik Indonesia: www.hukumonline.com, 2009, pp. 1-40.

[2] M. Er, D. Pranantha, and A. Ulya, "Penggunaan Algoritma Genetik Dengan Pemodelan Dua Tingkat Dalam Permasalahan Penjadwalan Perawat Pada Unit Gawat Darurat Rumah Sakit Umum XYZ Surabaya," pp. 1-9, 2008.

[3] Muhyi Y, "Penjadwalan kuliah otomatis dengan constraint programming. Seminar Nasional Teknologi Informasi (SNASTI)," 2008.

[4] R. Wulansari, Sistem Pendukung Keputusan Pembuatan jadwal Siar di Radio UMM FM dengan Menggunakan Metode SAW (Simple Addictive Weighting) dan Constraint SatisfacationNo Title. Universitan Muhammadiyah Malang, 2016.

[5] Y. Azhar, "Pengembangan Aplikasi Penjadwalan Mata Kuliah Dengan Menggunakan Algoritma Constraint Satisfaction," p. 5560222, 2009.

[6] Kenneth R. Baker and Trietsch, Principles of sequencing and scheduling. SONS, INC., 2009.

[7] G. Virginia and R. Delima, "Sistem rekomendasi pengambilan mata kuliah dengan menggunakan algoritma genetika dan metode constraint satisfaction," no. November, 2016.

[8] D. E. Ratnawati, D. Y. Liliana, R. Regasari, and L. Muflikhah, Modul Bahan Ajar Kecerdasan Buatan, Teknik Inf. Universitas Brawijaya, 2012.

[9] D. Mairiza, "Constraint Programming : Suatu Pendekatan dalam Declarative Programming."

[10] A. Fitri, I. Permana, and A. Marsal, "Penerapan Constraint Satisfaction Problem pada metode Priority Scheduling untuk Penjadwalan Khutbah Jum ' at para Mubaligh di IKMI Pekanbaru," vol. 13, no. 2, pp. 190-194, 2016. 